\title{
Epstein-Barr virus positive diffuse large B-cell lymphoma transformed into angioimmunoblastic T-cell lymphoma after treatment
}

Chaoyu Wang ${ }^{1}$, YI Gong ${ }^{1}$, Xiping Liang $^{1}$, and Rui Chen ${ }^{1}$

${ }^{1}$ chongqing cancer hospital

January 18, 2021

\begin{abstract}
To date, there is no report on the subsequent development of AITL in patients with EBV-positive DLBCL. We performed a rare case of EBV-positive AITL developing one year after initial diagnosis of EBV-positive DLBCL. The patient showed poor response to the chemotherapy regimen, and poor surviva
\end{abstract}

\section{Hosted file}

2020-12-30-manuscript.pdf available at https://authorea.com/users/390247/articles/ 504632-epstein-barr-virus-positive-diffuse-large-b-cell-lymphoma-transformed-intoangioimmunoblastic-t-cell-lymphoma-after-treatment

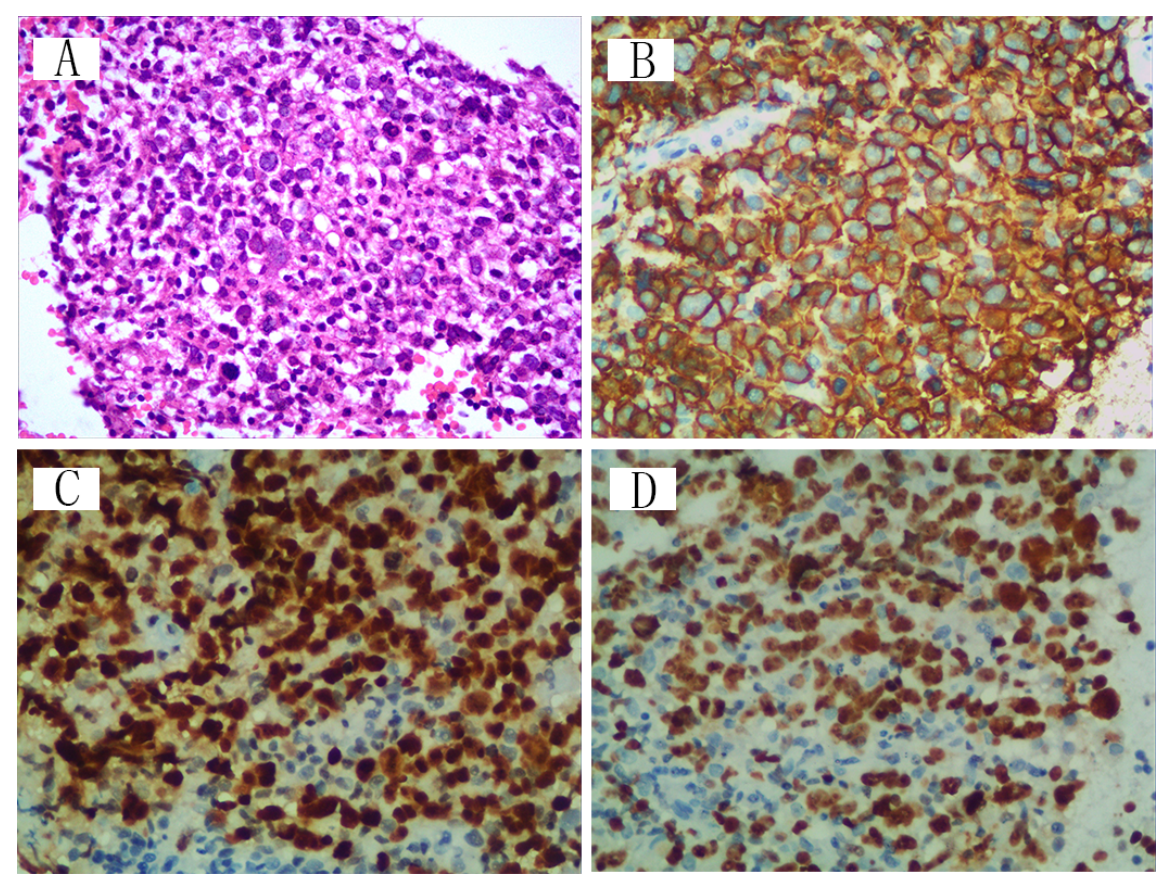




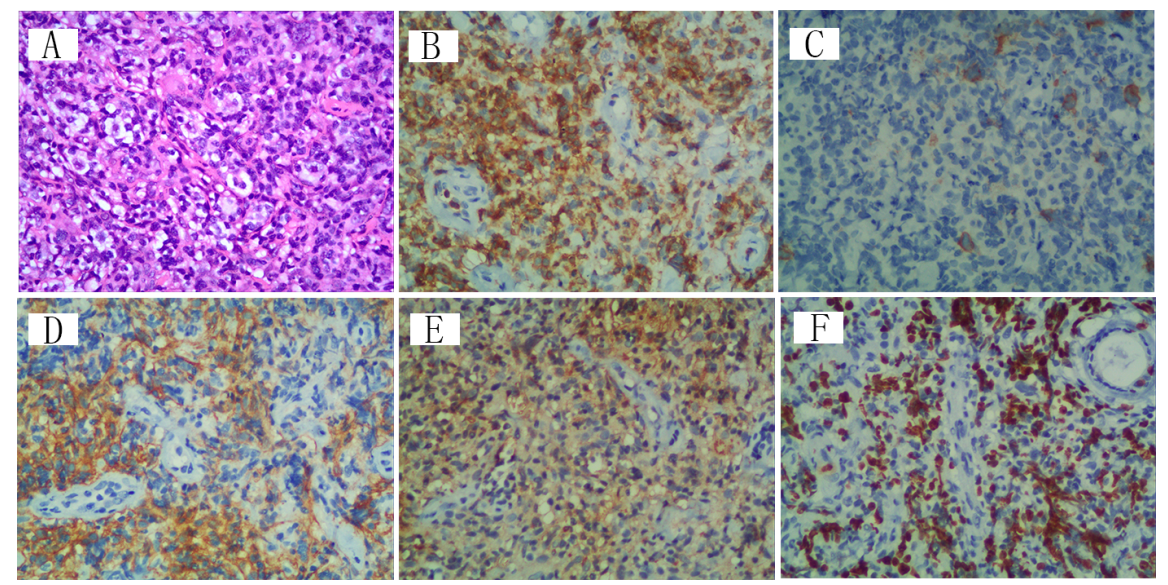

